\title{
Identification and Quantification of a Guanine-thymine Intrastrand Crosslink Lesion Induced by $\mathrm{Cu}(\mathrm{II}) / \mathrm{H}_{2} \mathrm{O}_{2} /$ Ascorbate
}

\author{
Haizheng Hong ${ }^{1}$, Huachuan $\mathrm{Cao}^{2}$, Yuesong Wang ${ }^{2}$, and Yinsheng Wang ${ }^{1,2,{ }^{*}}$ \\ 1 Environmental Toxicology Graduate Program, University of California at Riverside \\ 2Department of Chemistry, University of California at Riverside
}

\begin{abstract}
Reactive oxygen species (ROS) can be induced by both endogenous and exogenous processes and they can damage biological molecules including nucleic acids. It was shown that X- or $\gamma$-ray irradiation of aqueous solutions of DNA, during which $\mathrm{OH}$ is one of the major ROS, can lead to the formation of intrastrand crosslink lesions where the neighboring nucleobases in the same DNA strand are covalently bonded. Previous ${ }^{32} \mathrm{P}$-postlabeling studies suggested that the intrastrand crosslink lesions may arise from Fenton reaction, which also induces the formation of ${ }^{\circ} \mathrm{OH}$; the structures of the proposed intrastrand crosslink lesions, however, have not been determined. Here we showed for the first time that the treatment of calf thymus DNA with $\mathrm{Cu}(\mathrm{II}) / \mathrm{H}_{2} \mathrm{O}_{2}$ /ascorbate could lead to the formation of an intrastrand crosslink lesion, i.e., $\mathrm{G}^{\wedge} \mathrm{T}$, where the $\mathrm{C} 8$ of guanine is covalently bonded to the neighboring $3^{\prime}$ thymine through its methyl carbon. LC-MS/MS quantification results showed dose-responsive formation of $\mathrm{G}^{\wedge} \mathrm{T}$. In addition, the yield of the intrastrand crosslink was approximately three orders of magnitude lower than those of commonly observed single-base lesions, that is, 8-oxo-7,8-dihydro-2'-deoxyguanosine, 5-(hydroxymethyl)-2'-deoxyuridine and 5-formyl-2'deoxyuridine. The induction of intrastrand crosslink lesion in calf thymus DNA by Fenton reagents in vitro suggests that this type of lesion might be formed endogenously in mammalian cells.
\end{abstract}

\section{Introduction}

Reactive oxygen species (ROS) can be generated during normal aerobic metabolism or through exogenous pathways and excess generation of ROS in vivo results in damage to biological molecules including DNA (1-3). Some of the oxidatively generated DNA lesions may give rise to mutations. In this respect, the most frequently observed mutations resulting from ROSinduced DNA damage are $\mathrm{C} \rightarrow \mathrm{T}$ transitions and $\mathrm{G} \rightarrow \mathrm{T}$ transversions (4). In addition, unusual tandem double mutations, that is, $\mathrm{CC} \rightarrow \mathrm{TT}$ and $\mathrm{mCG} \rightarrow \mathrm{TT}$ substitutions, have been shown to be induced by ROS generated from a variety of systems (4-7). It was suggested that ROSinduced intrastrand crosslink lesions formed between adjacent nucleotides might contribute to the tandem base mutations $(5,6)$.

Previous work by Box, Cadet, Wang and their coworkers (8-20) uncovered that $\gamma$-or X-ray irradiation of aqueous solutions of DNA components can induce the formation of several intrastrand crosslink lesions. For instance, a $\mathrm{G}^{\wedge} \mathrm{T}$ intrastrand crosslink lesion, where the $\mathrm{C} 8$ of guanine is covalently bonded to the methyl carbon of its neighboring thymine, was shown to be induced in calf thymus DNA upon $\gamma$ irradiation (13). These previous studies also revealed that the intrastrand crosslink lesions are initiated from a single pyrimidine radical $(9-11,13$,

\footnotetext{
* To whom correspondence should be addressed: Department of Chemistry-027, University of California, Riverside, CA 92521-0403. Telephone: (951) 827-2700. Fax: (951) 827-4713. E-mail: yinsheng.wang@ucr.edu.
} 
15-17). In this regard, hydroxyl radical ( $\mathrm{OH})$ can either be added to the $\mathrm{C} 5$ and $\mathrm{C} 6$ carbon atoms of cytosine, thymine and 5-methylcytosine, or abstract a hydrogen atom from the 5methyl group of the latter two pyrimidine bases (21). Both processes lead to the formation of pyrimidine base-centered secondary radicals, which may attack their neighboring purine bases to yield intrastrand crosslink lesions (9-11,13,15-17).

Hydrogen peroxide $\left(\mathrm{H}_{2} \mathrm{O}_{2}\right)$ is freely diffusible in cellular environment and can potentially reach the nucleus (5) and interact with DNA-bound transition-metal ions, which lead to the formation of highly reactive species (22). Among the transition metals, copper is an important structural metal in chromatin $(23,24)$ and it can form stable complex with DNA [The association constants are $10^{9} \mathrm{M}$ for $\mathrm{Cu}(\mathrm{I}) / \mathrm{DNA}$ and $10^{4} \mathrm{M}$ for $\left.\mathrm{Cu}(\mathrm{II}) / \mathrm{DNA}\right]$ (25-27). Although debate exists in the literature about the importance of the roles of copper in $\mathrm{H}_{2} \mathrm{O}_{2}$-induced DNA damage in vivo $(28,29)$, most researchers believe that copper plays a significant role in $\mathrm{H}_{2} \mathrm{O}_{2}$-mediated DNA damage $(5,23,29,30)$. In-vitro studies showed that $\mathrm{Cu}$ (II) and $\mathrm{H}_{2} \mathrm{O}_{2}$, often with the addition of ascorbate, induce DNA strand breaks (31) as well as many types of single-base lesions (22). In addition, Liang and Dedon (32) found that $\mathrm{Cu}(\mathrm{II})$-induced DNA damage is enhanced while the DNA is packed into nucleosomes. In addition, treatment of mammalian chromatin with $\mathrm{H}_{2} \mathrm{O}_{2}$ and copper ions also resulted in thymine-tyrosine crosslink, where the methyl carbon of thymine was coupled to $\mathrm{C} 3$ of tyrosine ring (33).

$\mathrm{Cu}(\mathrm{II}) / \mathrm{H}_{2} \mathrm{O}_{2}$ /ascorbate-mediated formation of DNA single-base and DNA-protein crosslink lesions are believed to be induced through the site-specific formation of ${ }^{\circ} \mathrm{OH}$ or through the formation of a DNA-copper- $\mathrm{H}_{2} \mathrm{O}_{2}$ complex which exhibits similar reactivity as ${ }^{\circ} \mathrm{OH}$ and/or singlet oxygen (33-36). The mechanism underlying the formation of the DNA-protein crosslink is thought to result from $\mathrm{H}$ atom abstraction by ' $\mathrm{OH}$ from the methyl group of thymine, followed by the addition of the resultant methyl radical of thymine to the C-3 position of tyrosine ring $(33,37)$. In light of these previous studeis, we reason that the intrastrand crosslink lesions may also be induced by $\mathrm{Cu}(\mathrm{II}) / \mathrm{H}_{2} \mathrm{O}_{2}$ /ascorbate system. Along this line, Randerath and others (38-43) detected, by ${ }^{32} \mathrm{P}-$ postlabeling assay, several bulky DNA adducts that are induced endogenously in animal tissues or from the Fenton reaction mixture of synthetic oligodeoxynucleotides (ODNs). Interestingly, some of the bulky adducts were commonly produced in ODNs bearing specific dinucleotide sequences, suggesting that these adducts might be intrastrand crosslink lesions (41). These bulky lesions were also found in tissues from animals exposed to pro-oxidant chemicals, which firmly linked the formation of the bulky adducts to ROS $(40,44)$. Later, Randerath et al. (45) analyzed, by using thin-layer chromatography with synthetic dinucleotide standards, ${ }^{32} \mathrm{P}$-labeled DNA digests under nine different chromatographic solvent conditions and confirmed that some of the bulky DNA adducts contained the 8,5'-cyclo-2'-deoxyadenosine (cyclo-dA). The cyclo-dA bears a covalent bond between the $\mathrm{C} 8$ of adenine and the $\mathrm{C}_{5^{\prime}}$ carbon in the same nucleoside. It, however, has not been established whether intrastrand crosslink lesions, where two neighboring nucleobases are covalently bonded, can be induced by Fenton-type reagents.

To examine whether intrastrand crosslink lesions can be formed from Fenton-type reagents, here we incubated calf thymus DNA with $\mathrm{Cu}(\mathrm{II}) / \mathrm{H}_{2} \mathrm{O}_{2} /$ ascorbate and analyzed the enzymatic digestion products of the DNA samples by LC-MS/MS. Indeed we found that the $\mathrm{G}^{\wedge} \mathrm{T}$ lesion, which was previously shown to be generated by $\gamma$ irradiation (13), can be induced by $\mathrm{Cu}(\mathrm{II}) /$ $\mathrm{H}_{2} \mathrm{O}_{2}$ /ascorbate in a dose-dependent manner. To our knowledge, this is the first demonstration that a structurely defined intrastrand nucleobase-nucleobase crosslink lesion can be induced by Fenton-type reagents. 


\section{Experimental Procedures}

Copper(II) chloride, tri-n-butyltin deuteride, L-methionine, L-ascorbic acid, alkaline phosphatase and calf thymus DNA were from Sigma-Aldrich (St. Louis, MO). Hydrogen peroxide (30\%) and nuclease P1 were purchased from Fisher Scientific (Fair Lawn, NJ) and MP Biomedicals (Aurora, OH), respectively. Snake venom phosphodiesterase and calf spleen phosphodiesterase were obtained from US Biological (Swampscott, MA). The [2amino-1,3,7,9-1 ${ }^{15} \mathrm{~N}_{5}$ ]-2'-deoxyguanosine and urea- ${ }^{15} \mathrm{~N}_{2}$ were obtained from Medical Isotope Inc. (Pelham, NH) and Cambridge Isotope Laboratories (Andover, MA), respectively.

\section{Synthesis and characterization of compounds}

The structures of the isotope-labeled lesions are shown in Scheme 1, in which an asterisk indicates the sites where the nitrogen and hydrogen atoms were ${ }^{15} \mathrm{~N}$ and deuterium, respectively.

[1,3-15 $\mathrm{N}_{2}-2$ '-D]-5-Hydroxymethyl-2'-deoxyuridine (1)—The isotope-labeled 5-HmdU was synthesized using the multi-step procedures reported by Sowers et al. (46). ESI-MS: $\mathrm{m} / \mathrm{z}$ $260.1[\mathrm{M}-\mathrm{H}]^{-}, m / z 262.1[\mathrm{M}+\mathrm{H}]^{+} .{ }^{1} \mathrm{H}$ NMR $\left(\mathrm{D}_{2} \mathrm{O}\right): \delta 7.92(\mathrm{~s}, 1 \mathrm{H}, \mathrm{H}-6), 6.31(\mathrm{~d}, J=6.4$ $\left.\mathrm{Hz},{ }^{1} \mathrm{H}, \mathrm{H}-1^{\prime}\right), 4.50\left(\mathrm{dd}, J_{1}=4.1 \mathrm{~Hz}, J_{2}=7.0 \mathrm{~Hz},{ }^{1} \mathrm{H}, \mathrm{H}-3{ }^{\prime}\right), 4.40\left(\mathrm{~s}, 2 \mathrm{H}, \mathrm{CH}_{2}\right), 4.06(\mathrm{~m}, 1 \mathrm{H}$, $\left.\mathrm{H}-4^{\prime}\right), 3.85$ ( $\mathrm{m}, 2 \mathrm{H}, \mathrm{H}-5^{\prime}$ and $\left.\mathrm{H}-5^{\prime \prime}\right), 2.40$ (m, 1H, H-2').

[1,3-15 $\mathrm{N}_{2}-2$ '-D]-5-Formyl-2'-deoxyuridine-The labeled 5-FodU was prepared according to previously described procedures (46). ESI-MS: $m / z 258.0[\mathrm{M} \mathrm{-} \mathrm{H}]^{-}, m / z 260.1[\mathrm{M}+$ $\mathrm{H}]^{+} .{ }^{1} \mathrm{H}$ NMR $\left(\mathrm{D}_{2} \mathrm{O}\right): \delta 9.69(\mathrm{~s}, 1 \mathrm{H}, \mathrm{COH}), 8.77(\mathrm{~s}, 1 \mathrm{H}, \mathrm{H}-6), 6.27\left(\mathrm{~d}, J=5.9 \mathrm{~Hz}, 1 \mathrm{H}, \mathrm{H}-1^{\prime}\right)$, $4.49\left(\mathrm{dd}, J_{1}=4.5 \mathrm{~Hz}, J_{2}=8.1 \mathrm{~Hz}, 1 \mathrm{H}, \mathrm{H}-3^{\prime}\right), 4.14\left(\mathrm{~s}, 2 \mathrm{H}, \mathrm{CH}_{2}\right), 3.88\left(\mathrm{~m}, 1 \mathrm{H}, \mathrm{H}-4^{\prime}\right), 2.43(\mathrm{~m}$, $\left.1 \mathrm{H}, \mathrm{H}-2^{\prime}\right)$.

[2-amino-1,3,7,9-15 $\mathrm{N}_{5}$ ]-8-Oxo-2'-deoxyguanosine-The title compound was synthesized at low-mg scale following published procedures for the large-scale preparation of unlabeled 8-oxodG with some modifications $(47,48)$. [2-amino-1,3,7,9- $\left.{ }^{15} \mathrm{~N}_{5}\right]-2^{\prime}$ -

deoxyguanosine $(2 \mathrm{mg})$ was suspended in a mixture of acetonitrile $(60 \mu \mathrm{L})$ and water $(15 \mu \mathrm{L})$ and to which solution was added $N$-bromosuccinimide $(2.6 \mathrm{mg})$ in three portions. The mixture was stirred at room temperature for $30 \mathrm{~min}$. After the solvent was removed, ethyl ether $(1 \mathrm{~mL})$ was added to the mixture. The solution was stirred at room temperature for $2 \mathrm{~h}$ and then incubated at $-20{ }^{\circ} \mathrm{C}$ for overnight. The mixture was centrifuged and, after the supernatant was discarded, the precipitate was washed twice with cold acetone and dried to give [2amino-1,3,7,9-1 ${ }^{15} \mathrm{~N}_{5}$ ]-8-bromo-2'-deoxyguanosine.

Freshly-cut sodium ( $2 \mathrm{mg}$ ) was dissolved in benzyl alcohol $(\mathrm{BnOH}, 60 \mu \mathrm{L})$ at room temperature under argon atmosphere. The mixture was stirred for $3 \mathrm{~h}$ until the metal was dissolved. To the solution was then added the above [2-amino-1,3,7,9- $\left.{ }^{15} \mathrm{~N}_{5}\right]-8$-bromo-2'-deoxyguanosine and anhydrous DMSO $(40 \mu \mathrm{L})$. The reaction mixture was stirred at $65^{\circ} \mathrm{C}$ for $16 \mathrm{~h}$. After cooling down, the mixture was transferred into a stirred solution of ether $(1 \mathrm{~mL})$ for precipitation. The precipitate was washed with ether for three times and resuspended in a small portion of methanol. The solution $\mathrm{pH}$ was adjusted to 1.0 by adding $1 \mathrm{M} \mathrm{HCl}$ and the solution was stirred for $1 \mathrm{~h}$. After drying, the residue was dissolved in a small amount of methanol, and ether (1 $\mathrm{mL}$ ) was added to precipitate the residue. The precipitate was redissolved in water and purified by HPLC. ESI-MS: m/z $289.0[\mathrm{M}+\mathrm{H}]^{+}$.

Compounds 2-4 (Scheme 2)-These three compounds were synthesized starting from compound 1 following previously described procedures for the preparations of the corresponding unlabeled compounds (15). 
Compound 2-Yield: 46\%. ESI-MS: $m / z 354.0[\mathrm{M}+\mathrm{H}]^{+} .{ }^{1} \mathrm{H}$ NMR (DMSO- $d_{6}$ ): $\delta 11.45$

(s, 1H, NH), $7.67(\mathrm{~s}, 1 \mathrm{H}, \mathrm{H}-6), 7.33(\mathrm{~m}, 5 \mathrm{H}, \mathrm{Ar}-\mathrm{H}), 6.08\left(\mathrm{~d}, J_{\mathrm{H}^{\prime}-\mathrm{H} 2^{\prime}}=8.1 \mathrm{~Hz}, 1 \mathrm{H}, \mathrm{H}-1^{\prime}\right), 5.20$ $\left(\mathrm{d}, J_{\mathrm{OH}-\mathrm{H} 3^{\prime}}=3.9 \mathrm{~Hz}, 1 \mathrm{H}, 3^{\prime}-\mathrm{OH}\right), 5.00\left(\mathrm{t}, J_{\mathrm{OH}-\mathrm{H} 5^{\prime}}=4.5 \mathrm{~Hz}, 1 \mathrm{H}, 5^{\prime}-\mathrm{OH}\right), 4.16\left(\mathrm{~m}, 1 \mathrm{H}, \mathrm{H}-3^{\prime}\right)$, 3.79 (s, 2H, $\left.\mathrm{CH}_{2}-\mathrm{SPh}\right), 3.72$ (m, 1H, H-4'), 3.48 (m, 2H, H-5' and H-5”), 1.81 (m, 1H, H-2').

Compound 3-Yield: 70\%. ESI-MS: $m / z$ 654.1 [M - H] $]^{-}, 678.2[\mathrm{M}+\mathrm{Na}]^{+} .{ }^{1} \mathrm{H}$ NMR $\left(\mathrm{CDCl}_{3}\right): \delta 7.42-6.82(\mathrm{~m}, 19 \mathrm{H}, \mathrm{H} 6$, trityl and phenyl proton $), 6.23\left(\mathrm{~d}, J_{\mathrm{H}^{\prime}-\mathrm{H} 2^{\prime}}=7.6 \mathrm{~Hz}, 1 \mathrm{H}\right.$, H-1'), $4.34\left(\mathrm{dd}, J_{1}=3.5 \mathrm{~Hz}, J_{2}=6.4 \mathrm{~Hz}, 1 \mathrm{H}, \mathrm{H}-3^{\prime}\right), 3.97\left(\mathrm{~m}, 1 \mathrm{H}, \mathrm{H}-4^{\prime}\right), 3.74\left(\mathrm{~s}, 6 \mathrm{H}, \mathrm{O}^{\prime} \mathrm{CH}_{3}\right)$, $3.50(\mathrm{~d}, J=14.1 \mathrm{~Hz}, 1 \mathrm{H}, \mathrm{CH}-\mathrm{SPh}), 3.40\left(\mathrm{~d}, J=14.1 \mathrm{~Hz}, 1 \mathrm{H}, \mathrm{CH}^{\prime}-\mathrm{SPh}\right), 3.29\left(\mathrm{~m}, 2 \mathrm{H}, \mathrm{H}-5^{\prime}\right.$ and H-5”), 1.97(m, 1H, H-2').

Compound 4-Yield: 60\%. ESI-MS: $m / z 855.9[\mathrm{M}+\mathrm{H}]^{+}, 878.2[\mathrm{M}+\mathrm{Na}]^{+} .{ }^{31} \mathrm{P} \mathrm{NMR}$ $\left(\mathrm{CDCl}_{3}\right): \delta 150.18,149.58$.

Isotope-labeled $\mathbf{d}\left(\mathbf{G}^{\wedge} \mathbf{T}\right)$-With compound $\mathbf{4}$, we synthesized an oligodeoxynucleotide (ODN), d(CCGXGTGC), where X represents the isotope-incorporated 5-phenylthiomethyl-2'deoxyuridine, on a Beckman Oligo 1000S DNA synthesizer (Fullerton, CA) at $1-\mu \mathrm{mol}$ scale. The deprotection of the synthetic product was carried out by treatment with $29 \%$ ammonia at room temperature for $48 \mathrm{~h}$. The ODN was further purified and desalted by HPLC (See HPLC section).

An aqueous solution of the ODN with an $\mathrm{OD}_{260}$ of 0.4 was dispersed in a quartz tube and degassed by bubbling with argon for 30 min and irradiated with 254-nm UV light from a TLC lamp (UVGL-58, UVP Inc., Upland, CA) at room temperature for 15-20 min with continuous argon bubbling. The solution was dried in a Speed-Vac and reconstituted in water for digestion with a combination of four enzymes and the digestion mixture was separated by HPLC to obtain the isotope-labeled $\mathrm{d}\left(\mathrm{G}^{\wedge} \mathrm{T}\right)$ (vide infra).

d(ATGGCG^TGCTAT)—We synthesized unlabeled phosphoramidite building block $\mathbf{4}$ according to previously published procedures (15) and employed it to prepare a dodecameric ODN d(ATGGCGXGCTAT), where X represents the unlabeled 5-phenylthiomethyl-2'deoxyuridine. After deprotection and purification of the synthetic ODN, it was irradiated with 254-nm UV light under identical conditions as described above.

\section{Preparation of standard solutions of DNA lesions}

The concentrations of stock solutions of 5-FodU, 5-HmdU, 8-oxodG, and $\mathrm{d}\left(\mathrm{G}^{\wedge} \mathrm{T}\right)$ were determined by UV absorption spectroscopy. The extinction coefficients (in $\mathrm{L} / \mathrm{mol} / \mathrm{cm}$ ) used to quantify the standard solutions were: 5-FodU, $\varepsilon_{281}=13500 ; 5$-HmdU, $\varepsilon_{264}=10500$; 8-oxodG, $\varepsilon_{294}=9700(49) ; \mathrm{d}\left(\mathrm{G}^{\wedge} \mathrm{T}\right),{ }_{260}=25800$. The $\varepsilon_{260}$ for $\mathrm{d}\left(\mathrm{G}^{\wedge} \mathrm{T}\right)$ was determined by ${ }^{1} \mathrm{H}$ NMR (Figure S15) following the method described by Hong et al. (50).

\section{Treatment of calf thymus DNA}

Commercially available calf thymus DNA was desalted by ethanol precipitation. The DNA pellet was redissolved in a solution containing $50 \mathrm{mM} \mathrm{NaCl}$ and $20 \mathrm{mM}$ phosphate $(\mathrm{pH} 7.0)$ and the DNA was annealed by heating the solution to $90^{\circ} \mathrm{C}$ and cooling slowly to room temperature.

Aliquots of DNA (300 $\mu \mathrm{g})$ were incubated with $\mathrm{CuCl}_{2}(12.5-200 \mu \mathrm{M}), \mathrm{H}_{2} \mathrm{O}_{2}(0.1-1.6 \mathrm{mM})$ and ascorbate $(1-16 \mathrm{mM})$ in a $1-\mathrm{mL}$ solution containing $25 \mathrm{mM} \mathrm{NaCl}$ and $50 \mathrm{mM}$ phosphate $(\mathrm{pH}$ 7.0) at room temperature for $50 \mathrm{~min}$. In this respect, chemicals used in Fenton-type treatment of DNA were freshly dissolved in doubly distilled water and all the Fenton reactions were carried out under aerobic conditions. The detailed concentrations of individual Fenton reagents 
used for the reactions were shown in Table 1. Fenton-type reactions were terminated by adding excess amount of L-methionine, and the DNA samples were again desalted by ethanol precipitation. To examine the effect of residual transition metal ions in calf thymus DNA on the formation of DNA lesions, we also incubated calf thymus DNA with $400 \mu \mathrm{M} \mathrm{H}_{2} \mathrm{O}_{2}$ and 4 $\mathrm{mM}$ ascorbate without the addition of $\mathrm{Cu}$ (II) ions. In addition, experiments were carried out in the presence of $8 \mathrm{mM}$ dimethyl sulfoxide (DMSO), a hydroxyl radical scavenger, for Fenton reaction conditions $\mathrm{C}$ (Table 1). To examine the effect of ascorbate, calf thymus DNA was also incubated with $50 \mu \mathrm{M} \mathrm{CuCl} 2$ and $400 \mu \mathrm{M} \mathrm{H}_{2} \mathrm{O}_{2}$ alone.

\section{Enzymatic digestion of DNA}

Ten units of nuclease P1, 0.01 unit of calf spleen phosphodiesterase, and a 10- $\mu \mathrm{L}$ solution containing $300 \mathrm{mM}$ sodium acetate (pH 5.0) and $10 \mathrm{mM}$ zinc acetate were added to the calf thymus DNA sample and the digestion was carried out at $37^{\circ} \mathrm{C}$ for $6 \mathrm{~h}$. To the digestion mixture were then added 100 units of alkaline phosphatase, 0.05 unit of snake venom phosphodiesterase and $20 \mu \mathrm{L}$ of $0.5 \mathrm{M}$ Tris- $\mathrm{HCl}$ buffer $\left(\mathrm{pH} 8.9\right.$ ). The digestion was continued at $37^{\circ} \mathrm{C}$ for $6 \mathrm{~h}$, and the digestion mixture was passed through a 10-kDa Centricon membrane (Millipore, Billerica, MA) to remove the enzymes. The amount of nucleosides in the mixture was quantified by UV absorption spectroscopy, and to the mixture was then added isotopically labeled standard lesions, that is, 5-FodU, 5-HmdU, 8-oxodG, and $\mathrm{d}\left(\mathrm{G}^{\wedge} \mathrm{T}\right)$. The resulting aliquots were subjected directly to LC-MS/MS analysis or HPLC enrichment prior to LC-MS/ MS analysis.

The digestion of the UV irradiation mixture of $\mathrm{d}(\mathrm{CCGXGTGC)}$ as well as dodecameric $\mathrm{d}$ (ATGGCG^TGCTAT) was performed under similar conditions as for the digestion of calf thymus DNA.

\section{HPLC}

A $4.6 \times 250 \mathrm{~mm}$ Apollo C18 Column (5 $\mu \mathrm{m}$ in particle size, $300 \AA$ in pore size, Alltech Associate Inc., Deerfield, IL) was used for the separation of synthetic ODN, UV irradiated ODN d(ATGGCGXGCTAT), and the enzymatic digestion products of the UV-irradiation mixture of the $\mathrm{d}$ (CCGXGTGC). The flow rate was $0.8 \mathrm{~mL} / \mathrm{min}$. For the ODN separation, a solution of $50 \mathrm{mM}$ triethylammonium acetate (TEAA, solution A) and a mixture of $50 \mathrm{mM}$ TEAA and acetonitrile $(70 / 30, \mathrm{v} / \mathrm{v})$ (solution B) were used as mobile phases. A gradient of 5 $\min 0-20 \%$ B, $45 \min 20-50 \%$ B and $5 \min 50-100 \%$ B was employed. The separation of the enzymatic digestion mixture was carried out by using $10 \mathrm{mM}$ ammonium formate (solution A) and $30 \%$ acetonitrile in $10 \mathrm{mM}$ ammonium formate (solution B) as mobile phases, and the gradient was $20-\min 0-20 \% \mathrm{~B}, 30-\min 20-30 \%$ B followed by $15-\min 30-100 \% \mathrm{~B}$.

The HPLC enrichment of $d\left(G^{\wedge} T\right)$ from the digestion mixture of calf thymus DNA was performed with a $4.6 \times 50 \mathrm{~mm}$ Luna reverse-phase C18 column ( $5 \mu \mathrm{m}$ in particle size, Phenomenex, Torrance, CA). A gradient of 5-min $0-2 \%$ acetonitrile followed by a 55-min $2-5 \%$ acetonitrile in $10 \mathrm{mM}$ ammonium formate $(\mathrm{pH} 6.3)$ was employed and the flow rate was $0.30 \mathrm{~mL} / \mathrm{min}$. The HPLC fractions eluted between 18.5 and $24.5 \mathrm{~min}$ were pooled, and we collected fractions in a wide retention time range to ensure that crosslink product is completely collected. The collected fractions were dried in the Speed-vac, redissolved in $10 \mu \mathrm{L} \mathrm{H} 2 \mathrm{O}$, and injected for LC-MS/MS analysis.

\section{LC-MS/MS analysis}

A $0.5 \times 150 \mathrm{~mm}$ Zorbax SB-C18 column (particle size, $5 \mu \mathrm{m}$, Agilent) was used for the separation of the DNA hydrolysis samples, and the flow rate was $6.0 \mu \mathrm{L} / \mathrm{min}$, which was delivered by an Agilent 1100 capillary HPLC pump (Agilent Technologies, Palo Alto, CA). A 60 -min gradient of $0-30 \%$ acetonitrile in $20 \mathrm{mM}$ ammonium acetate was employed for the 
analysis of HPLC-enriched $d\left(\mathrm{G}^{\wedge} \mathrm{T}\right)$. The digested DNA samples were injected directly for the LC-MS/MS quantifications of 5-FodU, 5-HmdU, and 8-oxodG. A 60-min gradient of 0-35\% acetonitrile in $20 \mathrm{mM}$ ammonium acetate was used for the analysis of 8-oxodG and a slower gradient, in which the percentage of acetonitrile in $20 \mathrm{mM}$ ammonium acetate was increased from 0 to $15 \%$ over $60 \mathrm{~min}$, was employed for effective separation of 5-FodU and 5-HmdU.

The effluent from the LC column was coupled to an LCQ Deca XP ion-trap mass spectrometer (ThermoFinnigan, San Jose, CA), which was set up for monitoring the fragmentation of the $[\mathrm{M}+\mathrm{H}]^{+}$ions of the labeled and unlabeled 8-oxodG and $\mathrm{d}\left(\mathrm{G}^{\wedge} \mathrm{T}\right)$ or the $[\mathrm{M}-\mathrm{H}]^{-}$ions of the unlabeled and labeled 5-FodU and 5-HmdU.

\section{Results}

\section{Optimization of experimental conditions for the identification and quantification of $d\left(G^{\wedge} T\right)$}

Because the application of isotopically labeled internal standards can facilitate the unambiguous identification and accurate quantification of DNA lesions by LC-MS/MS, we synthesized stable-isotope-incorporated 5-FodU, 5-HmdU, 8-oxodG, and $\mathrm{d}\left(\mathrm{G}^{\wedge} \mathrm{T}\right)$ (Structures of these lesions are shown in Scheme 1). In this respect, the isotope-labeled single-base lesions were prepared following the previously published procedures (See Experimental Procedures. ESI-MS and MS/MS of the isotope-labeled nucleosides are shown in the Supporting Information).

To obtain the isotope-incorporated $\mathrm{d}\left(\mathrm{G}^{\wedge} \mathrm{T}\right)$, we prepared the phosphoramidite building block of stable isotope-labeled 5-phenylthiomethyl-2'-deoxyuridine (X, Scheme 2), incorporated it into an ODN, d(CCGXGTGC), irradiated the ODN with 254-nm light, digested the irradiation mixture with enzymes, and isolated the labeled $\mathrm{d}\left(\mathrm{G}^{\wedge} \mathrm{T}\right)$ from the digestion mixture by HPLC. The ESI-MS, MS/MS of the synthetic ODN and the labeled $\mathrm{d}\left(\mathrm{G}^{\wedge} \mathrm{T}\right)$ as well as the HPLC trace for the separation of the digested irradiation mixture are shown in the Supporting Information.

We also monitored the digestion mixture by LC-MS/MS, and it turned out that the $\mathrm{d}\left(\mathrm{T}^{\wedge} \mathrm{G}\right)$, if it were there, is formed at much lower yield than $\mathrm{d}\left(\mathrm{G}^{\wedge} \mathrm{T}\right)$. This is consistent with previous observations showing that intrastrand crosslink lesions are formed at much higher yield at 5'purine-pyrimidine-3' than at 5'-pyrimidine-purine-3' sites (13-15,17,50). In this context, it is worth noting that the product-ion spectra of the $[\mathrm{M}+\mathrm{H}]^{+}$ions of $\mathrm{d}\left(\mathrm{T}^{\wedge} \mathrm{G}\right)$, which was obtained from the 254-nm irradiation of $d(X G)$, and $d\left(G^{\wedge} T\right)$ are distinctive (Figure $S 16$ ).

To identify and quantify these lesions by LC-MS/MS with the above isotope-incorporated standards, we need to digest the oxidized calf thymus DNA down to mononucleosides (for unmodified nucleosides and single-base lesions examined here) or dinucleoside monophosphate (for $\mathrm{G}^{\wedge} \mathrm{T}$ ). In this respect, we chose the combination of four enzymes (i.e., nuclease P1, calf spleen phosphodiesterase, alkaline phosphatase and snake venom phosphodiesterase, see Experimental Procedures) for the digestion of the oxidized calf thymus DNA because the same set of enzymes have been employed successfully for the release of intrastrand crosslink lesions from duplex ODNs and calf thymus DNA $(13,17,50)$.

Here we further examined the efficiency of the enzymatic digestion procedure in liberating $\mathrm{G}^{\wedge} \mathrm{T}$ from ODNs. In this regard, we treated a solution, which contained a known amount of dodecameric d(ATGGCG^TGCTAT) and was spiked with a certain amount of isotope-labeled $\mathrm{d}\left(\mathrm{G}^{\wedge} \mathrm{T}\right)$, with the four enzymes and analyzed the digestion mixture by LC-MS/MS (The preparation and mass spectrometric characterizations of this lesion-carrying ODN are shown in Experimental Procedures). Under the enzymatic digestion conditions employed, we were able to recover approximately $88 \%$ of the unlabeled crosslink lesion in dinucleoside 
monophosphate form (Figure S8), showing that, under the current digestion conditions, most $\mathrm{G}^{\wedge} \mathrm{T}$ crosslink can be liberated as dinucleoside monophosphate.

We also assessed the detection limits for pure single-base lesions and $d\left(\mathrm{G}^{\wedge} \mathrm{T}\right)$ with our LCMS/MS method. It turned out that, at a signal-to-noise ratio $(\mathrm{S} / \mathrm{N})$ of 10 , the detection limits of pure $\mathrm{d}\left(\mathrm{G}^{\wedge} \mathrm{T}\right), 8$-oxodG, 5-HmdU, and 5-FodU on the LCQ Deca XP ion-trap mass spectrometer were $5 \mathrm{fmol}, 0.1 \mathrm{pmol}, 1 \mathrm{pmol}$, and $1 \mathrm{pmol}$, respectively. This level of sensitivity can allow us to detect $d\left(G^{\wedge} T\right)$ from $30 \mu \mathrm{g}$ calf thymus DNA with $S / N$ of 10 if $G^{\wedge} T$ is formed at a frequency of 5 lesions per $10^{8}$ normal nucleosides. In this context, it should be mentioned that the detection limits of the DNA lesions in the digested DNA samples might be somewhat poorer than those for the pure standards.

Because the single-base lesions, that is, 5-FodU, 5-HmdU and 8-oxodG, are produced in relatively high quantities (vide infra), their amounts can be determined by subjecting directly the digested DNA samples to LC-MS/MS analysis. However, the direct injection of the digested DNA samples into LC-MS/MS system cannot result in reasonably good signal for d $\left(G^{\wedge} T\right)$. To circumvent this, we enriched the intrastrand crosslink lesion, $d\left(G^{\wedge} T\right)$, by using HPLC with a $4.6 \times 50 \mathrm{~mm}$ column (See Experimental Procedures). To illustrate this, Figures S9 and S10 showed the LC-MS/MS results for the analysis of digestion mixture of $30 \mu \mathrm{g}$ of calf thymus DNA which was spiked with $25 \mathrm{fmol}$ of $\mathrm{d}\left(\mathrm{G}^{\wedge} \mathrm{T}\right)$ together with $250 \mathrm{fmol}$ of isotopically incorporated $d\left(G^{\wedge} T\right)$ that is with or without the HPLC enrichment. It is evident that the HPLC enrichment offers much better detection of the intrastrand crosslink lesion from the digested DNA sample. We reason that the enrichment procedure removes most salts used for the enzymatic digestion and most undamaged nucleosides thereby improving the ionization efficiency of $d\left(\mathrm{G}^{\wedge} \mathrm{T}\right)$. In addition, the removal of undamaged nucleosides may also improve the separation efficiency of the capillary column that was used for the LC-MS/MS experiments.

\section{LC-MS/MS identification and quantification of DNA lesions in calf thymus DNA oxidized with $\mathrm{Cu}(\mathrm{II}) / \mathrm{H}_{2} \mathrm{O}_{2} /$ ascorbate}

With the availability of isotope-incorporated lesions and the establishment of a sensitive detection method, we next treated calf thymus DNA with different concentrations of $\mathrm{Cu}(\mathrm{II}) /$ $\mathrm{H}_{2} \mathrm{O}_{2}$ /ascorbate (Table 1), hydrolyzed the DNA with the aforementioned four enzymes, and analyzed the resulting digestion mixtures by LC- MS/MS with stable isotope-labeled lesions as internal standards.

The selected-ion chromatogram (SIC) for the $m / z 570 \rightarrow 472$ transition, which monitors the loss of a 2'-deoxyribose component $\left(\mathrm{C}_{5} \mathrm{H}_{6} \mathrm{O}_{2}\right)$, showed a fraction eluting at the same time as the labeled $d\left(\mathrm{G}^{\wedge} \mathrm{T}\right)$ internal standard (Figure 1a-b, the sample was treated under condition $\mathrm{C}$ listed in Table 1). The product-ion spectrum of the ion of $m / z 570$ further supported the presence of $\mathrm{G}^{\wedge} \mathrm{T}$ in the enzymatic digestion mixture of the treated calf thymus DNA. Moreover, there was no detectable $\mathrm{d}\left(\mathrm{G}^{\wedge} \mathrm{T}\right)$ in the control sample without hydrogen peroxide treatment, showing that the $\mathrm{G}^{\wedge} \mathrm{T}$-intrastrand crosslink lesion can indeed be induced by Fenton-type reagents.

The ionizing radiation-induced formation of $\mathrm{G}^{\wedge} \mathrm{T}$ was thought to be initiated from the 5-(2'deoxyuridilyl)methyl radical, which was formed from the $\mathrm{OH}$-mediated hydrogen abstraction from the thymine methyl group. The secondary radical of thymine can then couple with the $\mathrm{C} 8$ of the vicinal $5^{\prime}$ guanine to give rise to the $\mathrm{G}^{\wedge} \mathrm{T}$ crosslink $(8,10,12,13)$. Given that ${ }^{`} \mathrm{OH}$ can also result in the formation of single-base lesions, it is important for us to quantify both the single-base and the intrastrand crosslink lesions. In this context, LC-MS/MS analysis also confirmed the induction of 5-FodU, 5-HmdU, and 8-oxodG in calf thymus DNA by the Fenton reagents (Figures S11-13). The quantification results showed that, at doses up to $800 \mu \mathrm{M}$ $\mathrm{H}_{2} \mathrm{O}_{2}$ and $100 \mu \mathrm{M} \mathrm{Cu}$ (II) (reaction conditions A-D in Table 1), the yields of the lesions were proportional to the concentrations of Fenton-type reagents (Figure 2, inset). 
At the highest dose, the yields of these lesions, however, fell out of the linear range (Figure 2). It was proposed that DNA-bound $\mathrm{Cu}(\mathrm{II})$ ions can react with $\mathrm{H}_{2} \mathrm{O}_{2}$ and ascorbate to generate site-specific hydroxyl radicals or form copper-peroxide complexes, which mediate the formation of single-base lesions $(22,23,36)$. We speculate that, at doses where the concentration of $\mathrm{Cu}$ (II) is lower than $100 \mu \mathrm{M}, \mathrm{Cu}$ (II) ions were bound to the nucleobases and mediated the oxidation of DNA bases in a dose-dependent manner. At the highest dose, some $\mathrm{Cu}$ (II) ions, however, might not be able to bind to nucleobases, which may result in lower yield of singlebase lesions than what we would extrapolate from the yields found at lower doses.

On the other hand, the dose-responsive curve of $\mathrm{d}\left(\mathrm{G}^{\wedge} \mathrm{T}\right)$ exhibited a different trend (Figure 3). Similar as what we observed for the above single-base lesions, the yields of $d\left(G^{\wedge} T\right)$ at low dose range were proportional to the concentrations of Fenton-type reagents, though the yields for $\mathrm{d}\left(\mathrm{G}^{\wedge} \mathrm{T}\right)$ were approximately three orders of magnitude lower than those of the single-base lesions (Figure 3, inset). However, when the DNA was treated with the highest dose of $\mathrm{Cu}(\mathrm{II}) /$ $\mathrm{H}_{2} \mathrm{O}_{2}$ /ascorbate $\left(\left[\mathrm{H}_{2} \mathrm{O}_{2}\right]=1600 \mu \mathrm{M}\right)$, the yield of $\mathrm{d}\left(\mathrm{G}^{\wedge} \mathrm{T}\right)$ increased considerably, which was 8 fold higher than the yield found at the second highest dose $\left(\left[\mathrm{H}_{2} \mathrm{O}_{2}\right]=800 \mu \mathrm{M}\right)$. The exact reason for the disproportionally high yield found at the highest dose is not clear, though we suspect that, at the highest dose, where the copper concentration is $200 \mu \mathrm{M}$, calf thymus DNA might adopt a conformation that is more favorable for the formation of the intrastrand crosslink lesion. In this respect, it was shown previously that copper binding can promote conformational change of DNA (51).

It is known that commercially available calf thymus DNA is often contaminated with trace amount of metal ions. According to previous flame absorption spectrometry results, the calf thymus DNA purchased from the Sigma-Aldrich contained $0.02 \mu \mathrm{M}$ of copper ions and 0.6 $\mu \mathrm{M}$ of iron in a solution containing $0.3 \mathrm{mg} / \mathrm{mL}$ of DNA (52). These amounts of metal ions were far below the concentration of copper added in the present work $(12.5-200 \mu \mathrm{M})$ and were therefore considered as negligible. In addition, it was shown that copper could not be removed from DNA by cation-exchange resin or by dialysis (52), thus we did not attempt to remove the residual metal ions from calf thymus DNA. To assess the effect of the residual metal ions in calf thymus DNA on the formation of oxidative single-base and $\mathrm{G}^{\wedge} \mathrm{T}$ lesions, we also conducted a control experiment where the calf thymus DNA was incubated with $\mathrm{H}_{2} \mathrm{O}_{2} /$ ascorbate alone. The results showed that, without the addition of $\mathrm{Cu}$ (II) ions, $400 \mu \mathrm{M} \mathrm{H}_{2} \mathrm{O}_{2}$ and $4 \mathrm{mM}$ of ascorbate only barely induced the formation of 8-oxodG, 5-HmdU, 5-FodU and $\mathrm{d}\left(\mathrm{G}^{\wedge} \mathrm{T}\right)$ (Figure $4 \mathrm{a}$ and $4 \mathrm{~b}$ ). Therefore, small amount of metal ions in calf thymus DNA did not contribute appreciably to the formation of oxidative DNA lesions discussed here.

\section{Mechanistic considerations}

Previous studies indicated that DNA double-strand breaks and single-base lesions induced by $\mathrm{Cu}(\mathrm{II}) / \mathrm{H}_{2} \mathrm{O}_{2}$, either in the presence or absence of ascorbate, may arise from site-specific $\cdot \mathrm{OH}$ generated from the DNA-bound copper ion or copper-peroxide complex $(22,23,34,36,53)$. To gain some insights into the mechanism for the formation of DNA intrastrand crosslink, we incubated calf thymus DNA with $\mathrm{Cu}(\mathrm{II}) / \mathrm{H}_{2} \mathrm{O}_{2} /$ ascorbate in the presence of a free ${ }^{\circ} \mathrm{OH}$ scavenger, DMSO, and compared the amounts of DNA lesions with that formed from the treatment with $\mathrm{Cu}(\mathrm{II}) / \mathrm{H}_{2} \mathrm{O}_{2}$ /ascorbate alone. The results showed that the incubation of DNA with Fenton-type reagents in the presence or absence of DMSO led to similar yields of singlebase lesions (Figure $4 \mathrm{a}$ ), which was consistent with the view that DNA single-base damages were mediated by DNA-bound copper ions $(22,23,36)$. Likewise, the presence of DMSO did not reduce markedly the yield of $\mathrm{d}\left(\mathrm{G}^{\wedge} \mathrm{T}\right)$ in calf thymus DNA treated with Fenton type reagents (Figure $4 \mathrm{~b}$ ), suggesting that the formation of DNA intrastrand crosslink followed a similar mechanism as the generation of single-base damage products. We also added DMSO to the incubation mixture of calf thymus DNA with the highest dose of $\mathrm{Cu}(\mathrm{II}) / \mathrm{H}_{2} \mathrm{O}_{2} /$ ascorbate 
(condition E in Table 1) and again found that DMSO did not reduce significantly the yield of $\mathrm{d}\left(\mathrm{G}^{\wedge} \mathrm{T}\right)$ at this dose (data not shown).

It should be mentioned that, without the addition of ascorbate, the yields of single-base and intrastrand crosslink lesions dropped significantly (Figure 4). Therefore, ascorbate is important for the induction of single-base and intrastrand crosslink lesions by $\mathrm{Cu}(\mathrm{II}) / \mathrm{H}_{2} \mathrm{O}_{2}$. This observation is not surprising in the viewpoint that, for the Fenton reaction to occur, copper needs to be in the reduced state:

$$
\mathrm{Cu}(\mathrm{I})+\mathrm{H}_{2} \mathrm{O}_{2} \rightarrow \mathrm{Cu}(\mathrm{II})+\mathrm{OH}+\mathrm{OH}^{-}
$$

In this context, DMSO is a scavenger for free ${ }^{\circ} \mathrm{OH}$, but it may not be effective in intercepting the $\mathrm{OH}$ generated from DNA-bound copper ion. Thus, the $\mathrm{OH}$ radical generated may preferentially react with the nearby nucleobase and give single-base and intrastrand crosslink lesions.

Recently, it was shown that singlet oxygen $\left({ }^{1} \mathrm{O}_{2}\right)$ might be the main active species involved in $\mathrm{Cu}(\mathrm{II}) / \mathrm{H}_{2} \mathrm{O}_{2}$-mediated DNA damage (49). Ascorbate is known to be a singlet oxygen $\left({ }^{1} \mathrm{O}_{2}\right)$ scavenger (54). Our experimental observations, therefore, appear to support that ${ }^{1} \mathrm{O}_{2}$ is not the major active species involved in the formation of $\mathrm{Cu}(\mathrm{II}) / \mathrm{H}_{2} \mathrm{O}_{2} /$ ascorbate-dependent DNA damages. Moreover, the presence of significant amount of thymidine oxidation products, 5FodU and 5-HmdU, also supported that ${ }^{1} \mathrm{O}_{2}$ was not the main effective ROS because ${ }^{1} \mathrm{O}_{2}$ specifically induces the formation of 8-oxodG, but not 5-FodU and 5-HmdU (55).

\section{Discussion}

We demonstrated for the first time that an intrastrand crosslink lesion which has a covalent bond formed between the $\mathrm{C} 8$ of guanine and the methyl carbon of its neighboring 3 '-thymine can be induced in calf thymus DNA by $\mathrm{Cu}(\mathrm{II}) / \mathrm{H}_{2} \mathrm{O}_{2} /$ ascorbate system. Copper is an important transition metal found in chromatin $(23,24)$. Our observations with calf thymus DNA suggest that the $\mathrm{Cu}(\mathrm{II})$-induced formation of DNA intrastrand crosslink lesions may also occur in vivo. The HPLC enrichment and the isotope dilution method described here set the stage for the sensitive detection of this and other types of intrastrand crosslink lesions formed in vivo.

In addition to the $\mathrm{G}^{\wedge} \mathrm{T}$ reported here, $8,5^{\prime}$-cyclo-2'-deoxyadenosine (cyclo-dA) was shown to be induced by Fenton-type reagents (45). In this regard, cyclo-dA was known to be a substrate for enzymes involved in nucleotide excision repair (NER), but not for those involved in base excision repair $(56,57)$. In addition, this lesion was a strong block to DNA polymerase $\delta(56)$ and RNA polymerase II (57). Recent in vitro repair studies also showed that $\mathrm{G}^{\wedge} \mathrm{T}$ can be recognized by the E. coli UvrABC nuclease (58). Although the effect of $\mathrm{G}^{\wedge} \mathrm{T}$ on DNA replication and transcription has not been explored, a structurely related $\mathrm{G}^{\wedge} \mathrm{C}$ crosslink, in which the $\mathrm{C} 8$ of guanine is covalently linked to the $\mathrm{C} 5$ of the neighboring $3^{\prime}$ cytosine, was shown to block DNA synthesis by replicative DNA polymerases $(20,59)$. In addition, the $\mathrm{G}^{\wedge} \mathrm{C}$ could be partially bypassed by yeast DNA polymerase $\eta$; the translesion synthesis, however, is error-prone (20).

Given that the intrastrand crosslink lesions are bona fide substrates for NER enzymes, these lesions may pose a challenge for people suffering from the genetic disease, xeroderma pigmentosum (XP), which is characterized by deficiency in NER (60). Along this line, it was shown that repair-defective cells from severe cases of XP appear to be incapable of removing a major type of oxidative DNA damage (61). ROS may generate abundant DNA intrastrand crosslink lesions in the central nervous system because neurons consume a large amount of oxygen. If not repaired, intrastrand crosslink lesions are expected to accumulate and be neurotoxic. This is consistent with the fact that XP patients suffer from a progressive, yet 
massive neuron loss with accompanying mental deterioration over a period of decades and also exhibit a markedly increased frequency of internal cancers (62). Therefore, the identification of the intrastrand crosslink lesion induced by Fenton reaction reported here may lead to further understanding of the role of the intrastrand crosslink lesions in the pathological symptoms of XP patients.

It is worth noting that the isotope-labeled standard and the off-line HPLC enrichment procedure are important for the sensitive detection of the intrastrand crosslink lesion, especially for the lesion induced at low dose range. In this respect, the application of isotope labeled internal standard facilitated the unambiguous identification and accurate quantification of the intrastrand crosslink by LC-MS/MS. The off-line HPLC enrichment cleaned the sample by removing buffer salts (used in the enzymatic digestion) and unmodified nucleosides, which improve the ionization efficiency of the target lesion and enhances the separation efficiency of the lesion on a capillary column. We envision that the approaches that we used here can be generally applicable for the sensitive detection of other types of DNA lesions.

\section{Supplementary Material}

Refer to Web version on PubMed Central for supplementary material.

\section{Acknowledgement}

The authors thank the National Institutes of Health for supporting this research (R01 CA96906).

\section{Abbreviations}

ROS, reactive oxygen species; ODN, oligodeoxynucleotides; Cyclo-dA, 8,5'-cyclo-2'deoxyadenosine; $\mathrm{G}^{\wedge} \mathrm{T}$, guanine-thymine crosslink; 8-oxodG, 8-oxo-7,8-dihydro-2'deoxyguanosine; 5-HmdU, 5-(hydroxymethyl)-2'-deoxyuridine; 5-FodU, 5-formyl-2'deoxyuridine; SIC, selected-ion chromatogram..

\section{References}

(1). Lindahl T. DNA lesions generated in vivo by reactive oxygen species, their accumulation and repair. NATO ASI Ser., Ser. A 1999;302:251-257.

(2). Finkel T, Holbrook NJ. Oxidants, oxidative stress and the biology of ageing. Nature 2000;408:239247. [PubMed: 11089981]

(3). Marnett LJ. Oxyradicals and DNA damage. Carcinogenesis 2000;21:361-370. [PubMed: 10688856]

(4). Feig DI, Reid TM, Loeb LA. Reactive oxygen species in tumorigenesis. Cancer Res 1994;54:1890s1894s. [PubMed: 8137306]

(5). Lee DH, O'Connor TR, Pfeifer GP. Oxidative DNA damage induced by copper and hydrogen peroxide promotes CG--> TT tandem mutations at methylated $\mathrm{CpG}$ dinucleotides in nucleotide excision repair-deficient cells. Nucleic Acids Res 2002;30:3566-3573. [PubMed: 12177298]

(6). Reid TM, Loeb LA. Tandem double CC--> TT mutations are produced by reactive oxygen species. Proc. Natl. Acad. Sci. USA 1993;90:3904-3907. [PubMed: 8483909]

(7). Newcomb TG, Allen KJ, Tkeshelashvili L, Loeb LA. Detection of tandem CC-->TT mutations induced by oxygen radicals using mutation-specific PCR. Mutat. Res 1999;427:21-30. [PubMed: 10354498]

(8). Box HC, Budzinski EE, Dawidzik JD, Wallace JC, Evans MS, Gobey JS. Radiation-induced formation of a crosslink between base moieties of deoxyguanosine and thymidine in deoxygenated solutions of d(CpGpTpA). Radiat. Res 1996;145:641-643. [PubMed: 8619032]

(9). Box HC, Budzinski EE, Dawidzik JB, Gobey JS, Freund HG. Free radical-induced tandem base damage in DNA oligomers. Free Radic. Biol. Med 1997;23:1021-1030. [PubMed: 9358245] 
(10). Box HC, Budzinski EE, Dawidzik JB, Wallace JC, Iijima H. Tandem lesions and other products in X-irradiated DNA oligomers. Radiat. Res 1998;149:433-439. [PubMed: 9588353]

(11). Budzinski EE, Dawidzik JB, Rajecki MJ, Wallace JC, Schroder EA, Box HC. Isolation and characterization of the products of anoxic irradiation of d(CpGpTpA). Int. J. Radiat. Biol 1997;71:327-336. [PubMed: 9134023]

(12). Romieu A, Bellon S, Gasparutto D, Cadet J. Synthesis and UV photolysis of oligodeoxynucleotides that contain 5-(phenylthiomethyl)-2'-deoxyuridine: a specific photolabile precursor of 5-(2'deoxyuridilyl)methyl radical. Org. Lett 2000;2:1085-1088. [PubMed: 10804560]

(13). Bellon S, Ravanat JL, Gasparutto D, Cadet J. Cross-linked thymine-purine base tandem lesions: synthesis, characterization, and measurement in gamma-irradiated isolated DNA. Chem. Res. Toxicol 2002;15:598-606. [PubMed: 11952347]

(14). Zeng Y, Wang Y. Facile formation of an intrastrand cross-link lesion between cytosine and guanine upon pyrex-filtered UV light irradiation of $\mathrm{d}\left({ }^{\mathrm{Br}} \mathrm{CG}\right)$ and duplex DNA containing 5-bromocytosine. J. Am. Chem. Soc 2004;126:6552-6553. [PubMed: 15161273]

(15). Zhang Q, Wang Y. Independent generation of 5-(2'-deoxycytidinyl)methyl radical and the formation of a novel cross-link lesion between 5-methylcytosine and guanine. J. Am. Chem. Soc 2003;125:12795-12802. [PubMed: 14558827]

(16). Zhang Q, Wang Y. Independent generation of the 5-hydroxy-5,6-dihydrothymidin-6-yl radical and its reactivity in dinucleoside monophosphates. J. Am. Chem. Soc 2004;126:13287-13297. [PubMed: 15479083]

(17). Zhang Q, Wang Y. Generation of 5-(2'-deoxycytidyl)methyl radical and the formation of intrastrand cross-link lesions in oligodeoxyribonucleotides. Nucleic Acids Res 2005;33:1593-1603. [PubMed: 15767284]

(18). Liu Z, Gao Y, Wang Y. Identification and characterization of a novel cross-link lesion in $\mathrm{d}(\mathrm{CpC})$ upon 365-nm irradiation in the presence of 2-methyl-1,4-naphthoquinone. Nucleic Acids Res 2003;31:5413-5424. [PubMed: 12954778]

(19). Liu Z, Gao Y, Zeng Y, Fang F, Chi D, Wang Y. Isolation and characterization of a novel cross-link lesion in $\mathrm{d}(\mathrm{CpC})$ induced by one-electron photooxidation. Photochem. Photobiol 2004;80:209-215. [PubMed: 15244508]

(20). Gu C, Wang Y. LC-MS/MS identification and yeast polymerase eta bypass of a novel gammairradiation-induced intrastrand cross-link lesion G[8-5]C. Biochemistry 2004;43:6745-6750. [PubMed: 15157108]

(21). von Sonntag, C. The chemical basis of radiation biology. Talor \& Francis; London: 1987.

(22). Aruoma OI, Halliwell B, Gajewski E, Dizdaroglu M. Copper-ion-dependent damage to the bases in DNA in the presence of hydrogen peroxide. Biochem. J 1991;273:601-604. [PubMed: 1899997]

(23). Drouin R, Rodriguez H, Gao SW, Gebreyes Z, O’Connor TR, Holmquist GP, Akman SA. Cupric ion/ascorbate/hydrogen peroxide-induced DNA damage: DNA-bound copper ion primarily induces base modifications. Free Radic. Biol. Med 1996;21:261-273. [PubMed: 8855437]

(24). Agarwal K, Sharma A, Talukder G. Effects of copper on mammalian cell components. Chem. Biol. Interact 1989;69:1-16. [PubMed: 2464442]

(25). Bach D, Miller IR. Polarographic investigation of binding of $\mathrm{Cu}++$ and $\mathrm{Cd}++$ by DNA. Biopolymers 1967;5:161-172. [PubMed: 6040714]

(26). Bryan SE, Frieden E. Interaction of copper(II) with deoxyribonucleic acid below 30 degrees. Biochemistry 1967;6:2728-2734. [PubMed: 6069709]

(27). Prutz WA, Butler J, Land EJ. Interaction of copper(I) with nucleic acids. Int. J. Radiat. Biol 1990;58:215-234. [PubMed: 1974571]

(28). Barbouti A, Doulias PT, Zhu BZ, Frei B, Galaris D. Intracellular iron, but not copper, plays a critical role in hydrogen peroxide-induced DNA damage. Free Radic. Biol. Med 2001;31:490-498. [PubMed: 11498282]

(29). Bar-Or D, Winkler JV. Copper is involved in hydrogen-peroxide-induced DNA damage. Free Radic. Biol. Med 2002;32:197-199. [PubMed: 11796209]

(30). Ames BN, Gold LS. Endogenous mutagens and the causes of aging and cancer. Mutat. Res 1991;250:3-16. [PubMed: 1944345] 
(31). Sagripant JL, Kraemer KH. Site-specific oxidative DNA damage at polyguanosines produced by copper plus hydrogen peroxide. J. Biol. Chem 1989;264:1729-1734. [PubMed: 2912981]

(32). Liang Q, Dedon PC. $\mathrm{Cu}(\mathrm{II}) / \mathrm{H} 2 \mathrm{O} 2$-induced DNA damage is enhanced by packaging of DNA as a nucleosome. Chem. Res. Toxicol 2001;14:416-422. [PubMed: 11304130]

(33). Nackerdien Z, Rao G, Cacciuttolo MA, Gajewski E, Dizdaroglu M. Chemical nature of DNA-protein cross-links produced in mammalian chromatin by hydrogen peroxide in the presence of iron or copper ions. Biochemistry 1991;30:4873-4879. [PubMed: 2036356]

(34). Lloyd DR, Phillips DH. Oxidative DNA damage mediated by copper(II), iron(II) and nickel(II) fenton reactions: evidence for site-specific mechanisms in the formation of double-strand breaks, 8-hydroxydeoxyguanosine and putative intrastrand cross-links. Mutat. Res 1999;424:23-36. [PubMed: 10064847]

(35). Oikawa S, Kawanishi S. Distinct mechanisms of site-specific DNA damage induced by endogenous reductants in the presence of iron(III) and copper(II). Biochim. Biophys. Acta 1998;1399:19-30. [PubMed: 9714716]

(36). Yamamoto K, Kawanishi S. Hydroxyl free radical is not the main active species in site-specific DNA damage induced by copper (II) ion and hydrogen peroxide. J. Biol. Chem 1989;264:1543515440. [PubMed: 2549063]

(37). Dizdaroglu M, Gajewski E, Reddy P, Margolis SA. Structure of a hydroxyl radical induced DNAprotein cross-link involving thymine and tyrosine in nucleohistone. Biochemistry 1989;28:36253628. [PubMed: 2545260]

(38). Randerath K, Reddy MV, Disher RM. Age- and tissue-related DNA modifications in untreated rats: detection by 32P-postlabeling assay and possible significance for spontaneous tumor induction and aging. Carcinogenesis 1986;7:1615-1617. [PubMed: 3742734]

(39). Randerath K, Yang PF, Danna TF, Reddy R, Watson WP, Randerath E. Bulky adducts detected by 32P-postlabeling in DNA modified by oxidative damage in vitro. Comparison with rat lung Icompounds. Mutat. Res 1991;250:135-144. [PubMed: 1944328]

(40). Randerath E, Watson WP, Zhou GD, Chang J, Randerath K. Intensification and depletion of specific bulky renal DNA adducts (I-compounds) following exposure of male F344 rats to the renal carcinogen ferric nitrilotriacetate (Fe-NTA). Mutat. Res 1995;341:265-279. [PubMed: 7531286]

(41). Randerath K, Randerath E, Smith CV, Chang J. Structural origins of bulky oxidative DNA adducts (type II I-compounds) as deduced by oxidation of oligonucleotides of known sequence. Chem. Res. Toxicol 1996;9:247-254. [PubMed: 8924599]

(42). Randerath K, Randerath E, Zhou GD, Li D. Bulky endogenous DNA modifications (I-compounds) -possible structural origins and functional implications. Mutat. Res 1999;424:183-194. [PubMed: 10064860]

(43). Carmichael PL, She MN, Phillips DH. Detection and characterization by ${ }^{32} \mathrm{P}$-postlabelling of DNA adducts induced by a Fenton-type oxygen radical-generating system. Carcinogenesis 1992;13:1127-1135. [PubMed: 1638678]

(44). Chang J, Watson WP, Randerath E, Randerath K. Bulky DNA-adduct formation induced by Ni(II) in vitro and in vivo as assayed by ${ }^{32} \mathrm{P}$-postlabeling. Mutat. Res 1993;291:147-159. [PubMed: 7680419]

(45). Randerath K, Zhou GD, Somers RL, Robbins JH, Brooks PJ. A ${ }^{32}$ P-postlabeling assay for the oxidative DNA lesion 8,5'-cyclo-2'-deoxyadenosine in mammalian tissues: evidence that four type II I-compounds are dinucleotides containing the lesion in the $3^{\prime}$ nucleotide. J. Biol. Chem 2001;276:36051-36057. [PubMed: 11454870]

(46). LaFrancois CJ, Fujimoto J, Sowers LC. Synthesis and characterization of isotopically enriched pyrimidine deoxynucleoside oxidation damage products. Chem. Res. Toxicol 1998;11:75-83. [PubMed: 9477229]

(47). Gillet LC, Scharer OD. Preparation of C8-amine and acetylamine adducts of 2'-deoxyguanosine suitably protected for DNA synthesis. Org. Lett 2002;4:4205-4208. [PubMed: 12443059]

(48). Nampalli S, Kumar S. Efficient synthesis of 8-oxo-dGTP: a mutagenic nucleotide. Bioorg. Med. Chem. Lett 2000;10:1677-1679. [PubMed: 10937723] 
(49). Frelon S, Douki T, Ravanat JL, Pouget JP, Tornabene C, Cadet J. High-performance liquid chromatography--tandem mass spectrometry measurement of radiation-induced base damage to isolated and cellular DNA. Chem. Res. Toxicol 2000;13:1002-1010. [PubMed: 11080049]

(50). Hong H, Wang Y. Formation of intrastrand cross-link products between cytosine and adenine from UV irradiation of $\mathrm{d}\left({ }^{\mathrm{Br}} \mathrm{CA}\right)$ and duplex DNA containing a 5-bromocytosine. J. Am. Chem. Soc 2005;127:13969-13977. [PubMed: 16201819]

(51). Trumbore CN, Ehrlich RS, Myers YN. Changes in DNA conformation induced by gamma irradiation in the presence of copper. Radiat. Res 2001;155:453-465. [PubMed: 11182797]

(52). Frelon S, Douki T, Favier A, Cadet J. Hydroxyl radical is not the main reactive species involved in the degradation of DNA bases by copper in the presence of hydrogen peroxide. Chem Res Toxicol 2003;16:191-197. [PubMed: 12588190]

(53). Lloyd DR, Carmichael PL, Phillips DH. Comparison of the formation of 8-hydroxy-2'deoxyguanosine and single- and double-strand breaks in DNA mediated by fenton reactions. Chem. Res. Toxicol 1998;11:420-427. [PubMed: 9585472]

(54). Shi M, Xu B, Azakami K, Morikawa T, Watanabe K, Morimoto K, Komatsu M, Aoyama K, Takeuchi T. Dual role of vitamin $\mathrm{C}$ in an oxygen-sensitive system: discrepancy between DNA damage and cell death. Free Radic. Res 2005;39:213-220. [PubMed: 15763969]

(55). Ravanat JL, Di Mascio P, Martinez GR, Medeiros MHG, Cadet J. Singlet oxygen induces oxidation of cellular DNA. J. Biol. Chem 2000;275:40601-40604. [PubMed: 11007783]

(56). Kuraoka I, Bender C, Romieu A, Cadet J, Wood RD, Lindahl T. Removal of oxygen free-radicalinduced 5',8-purine cyclodeoxynucleosides from DNA by the nucleotide excision-repair pathway in human cells. Proc. Natl. Acad. Sci. USA 2000;97:3832-3837. [PubMed: 10759556]

(57). Brooks PJ, Wise DS, Berry DA, Kosmoski JV, Smerdon MJ, Somers RL, Mackie H, Spoonde AY, Ackerman EJ, Coleman K, Tarone RE, Robbins JH. The oxidative DNA lesion 8,5'-(S)-cyclo-2'deoxyadenosine is repaired by the nucleotide excision repair pathway and blocks gene expression in mammalian cells. J. Biol. Chem 2000;275:22355-22362. [PubMed: 10801836]

(58). Yang Z, Colis LC, Basu AK, Zou Y. Recognition and incision of gamma-radiation-induced crosslinked guanine-thymine tandem lesion G[8,5-Me]T by UvrABC nuclease. Chem. Res. Toxicol 2005;18:1339-1346. [PubMed: 16167825]

(59). Gu C, Wang Y. Thermodynamic and in vitro replication studies of an intrastrand G[8-5]C crosslink lesion. Biochemistry 2005;44:8883-8889. [PubMed: 15952795]

(60). Berneburg M, Lehmann AR. Xeroderma pigmentosum and related disorders: defects in DNA repair and transcription. Adv. Genet 2001;43:71-102. [PubMed: 11037299]

(61). Satoh MS, Jones CJ, Wood RD, Lindahl T. DNA excision-repair defect of xeroderma pigmentosum prevents removal of a class of oxygen free radical-induced base lesions. Proc. Natl. Acad. Sci. USA 1993;90:6335-6339. [PubMed: 8327515]

(62). Cleaver, JE.; Kraemer, KH. The Metabolic Basis of Inherited Disease. Scriver, C.; Beaudet, AL.; Sly, WS.; Vale, D., editors. McGraw-Hill; New York: 1989. p. 2949-2971. 

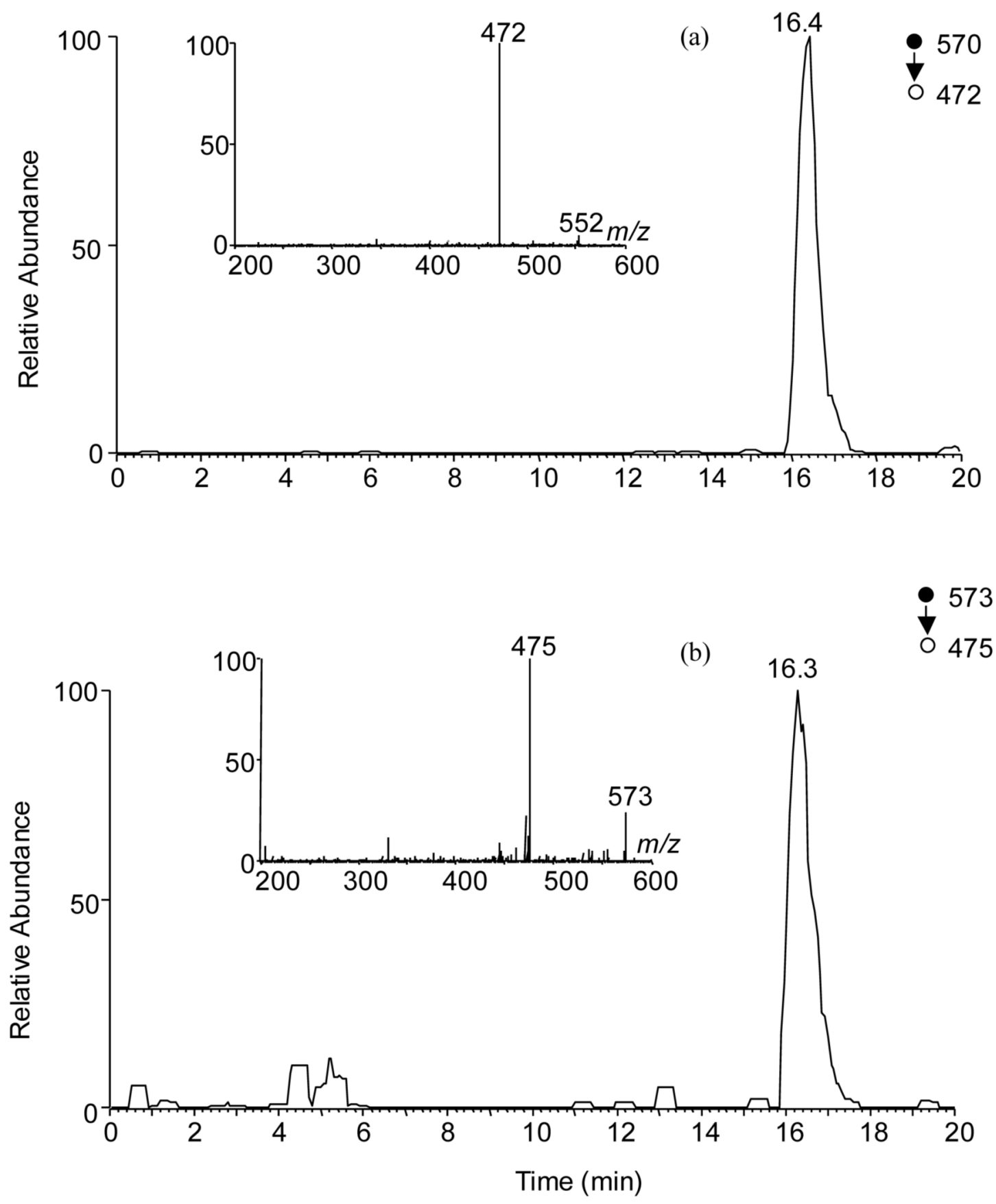

Figure 1.

Selected-ion chromatograms (SICs) for the monitoring of the $m / z 570 \rightarrow 472$ [a, for unlabeled $\left.\mathrm{d}\left(\mathrm{G}^{\wedge} \mathrm{T}\right)\right]$ and $573 \rightarrow 475\left[\mathrm{~b}\right.$, for labeled $\left.\mathrm{d}\left(\mathrm{G}^{\wedge} \mathrm{T}\right)\right]$ transitions in the $\mathrm{Cu} / \mathrm{H}_{2} \mathrm{O}_{2}$ /ascorbate-treated calf thymus DNA after enzymatic digestion. Shown in the insets are the product-ion spectra of the $[\mathrm{M}+\mathrm{H}]^{+}$ions of the unlabeled and labeled $d\left(\mathrm{G}^{\wedge} \mathrm{T}\right)$. 


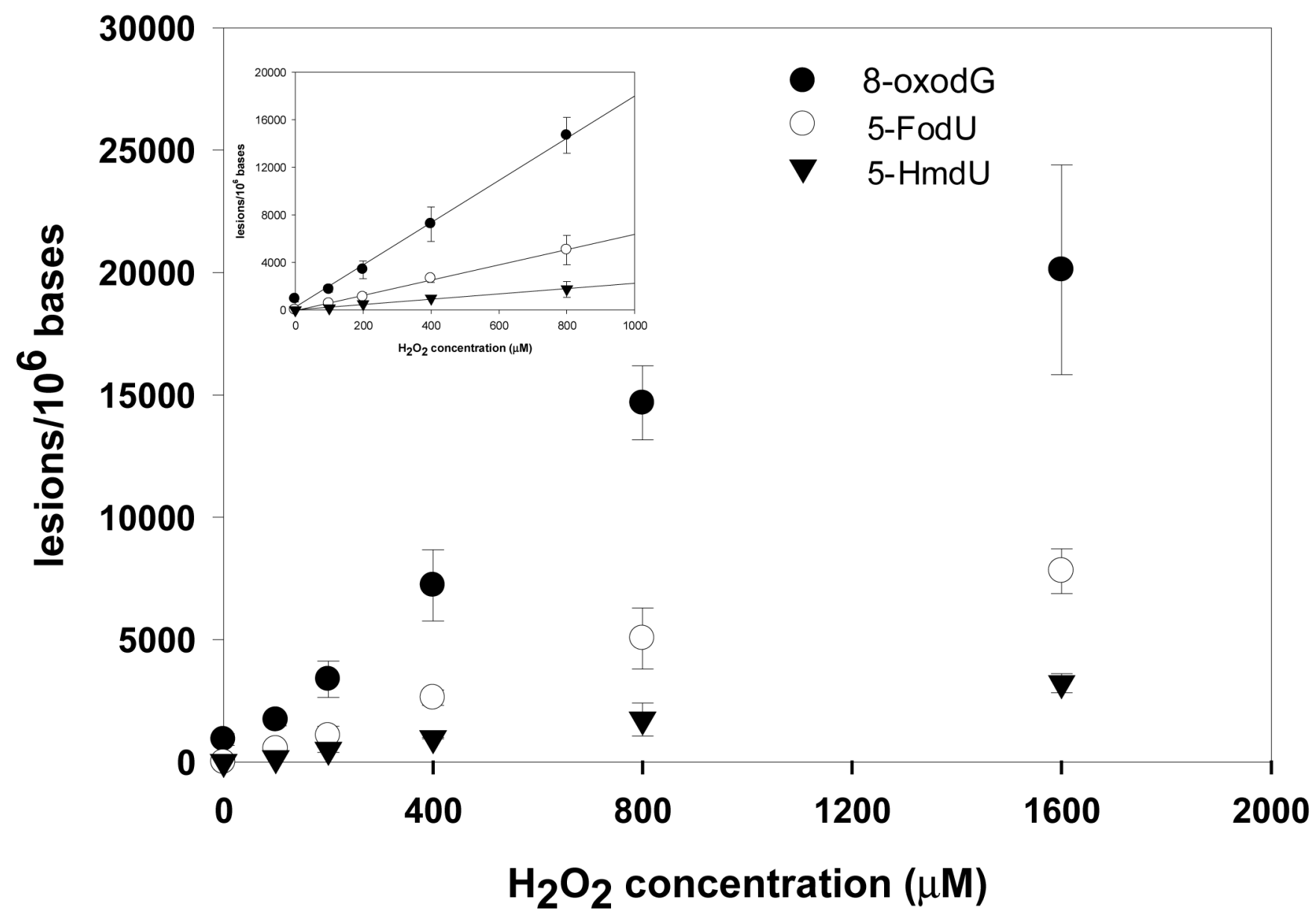

Figure 2.

$\mathrm{Cu}(\mathrm{II}) / \mathrm{H}_{2} \mathrm{O}_{2}$ /ascorbate-induced formation of 8-oxodG (•), 5-FodU (०) and 5-HmdU ( $\left.\theta\right)$ in the calf thymus DNA. The values represent the mean \pm SD from three independent oxidation and quantification experiments. The inset shows that the yields of the three single-base lesions were proportional to the concentrations of Fenton-type reagents at low dose range. 


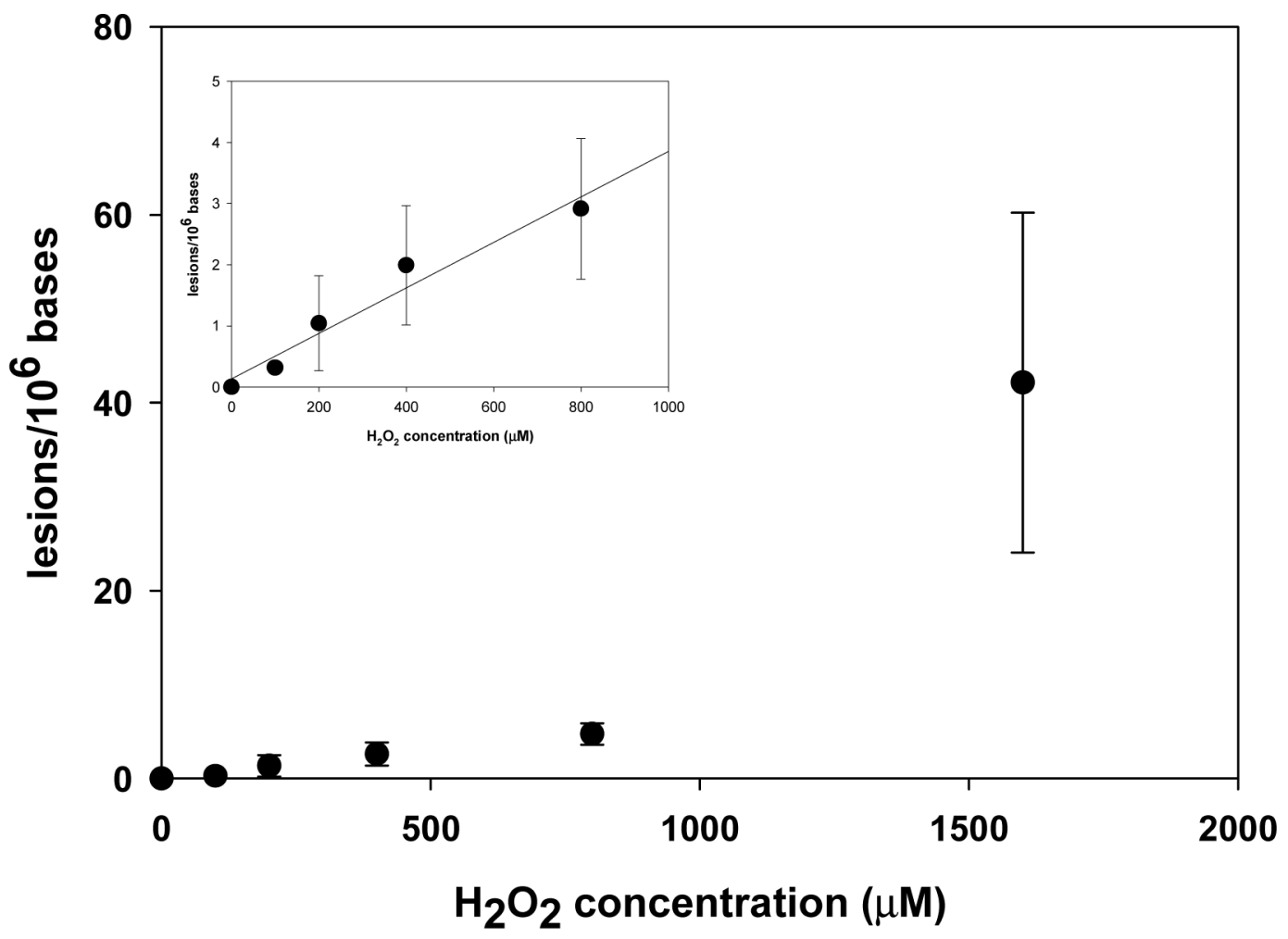

Figure 3.

$\mathrm{Cu}(\mathrm{II}) / \mathrm{H}_{2} \mathrm{O}_{2}$ /ascorbate-induced formation of $\mathrm{d}\left(\mathrm{G}^{\wedge} \mathrm{T}\right)$ in the calf thymus DNA. The values represent the mean \pm SD from three independent oxidation and quantification experiments. The inset shows that the formation of $d\left(\mathrm{G}^{\wedge} \mathrm{T}\right)$ was proportional to the concentration of Fentontype reagents at low dose range. 

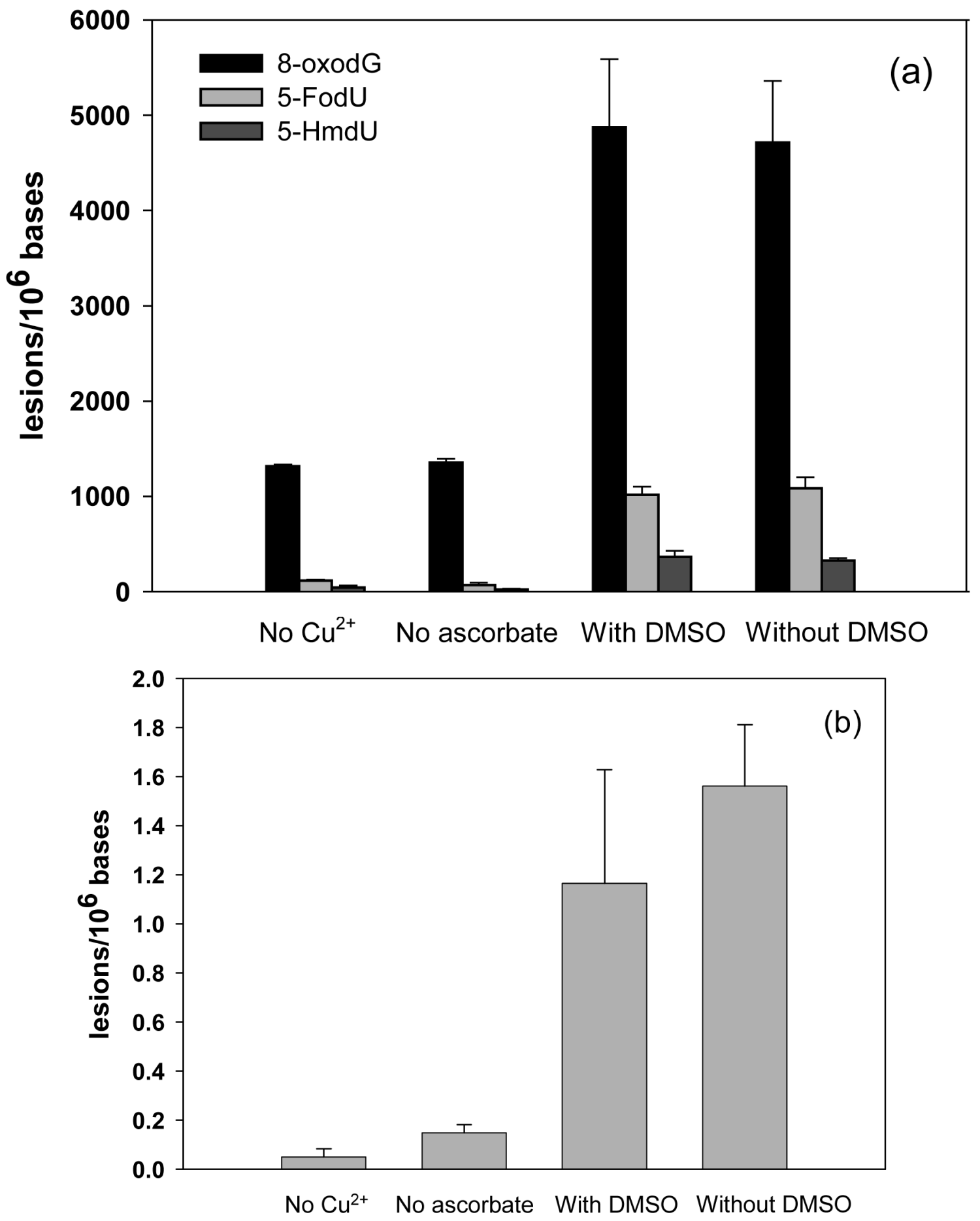

Figure 4.

(a) Formation of 5-FodU, 5-HmdU, and 8-oxodG under different oxidation conditions. (b) Formation of $\mathrm{d}\left(\mathrm{G}^{\wedge} \mathrm{T}\right)$ under different oxidation conditions. The data represent mean $\pm \mathrm{SD}$ from three independent experiments. No Cu2+: $400 \mu \mathrm{M} \mathrm{H}_{2} \mathrm{O}_{2}$ and $4 \mathrm{mM}$ ascorbate; No ascorbate: $400 \mu \mathrm{M} \mathrm{H}_{2} \mathrm{O}_{2}$ and $50 \mu \mathrm{M} \mathrm{Cu}^{2+}$; with DMSO: $400 \mu \mathrm{M} \mathrm{H}_{2} \mathrm{O}_{2}, 50 \mu \mathrm{M} \mathrm{Cu}^{2+}, 4 \mathrm{mM}$ ascorbate and $8 \mathrm{mM}$ DMSO; without DMSO: $400 \mu \mathrm{M} \mathrm{H}_{2} \mathrm{O}_{2}, 50 \mu \mathrm{M} \mathrm{Cu}^{2+}$ and $4 \mathrm{mM}$ ascorbate. 

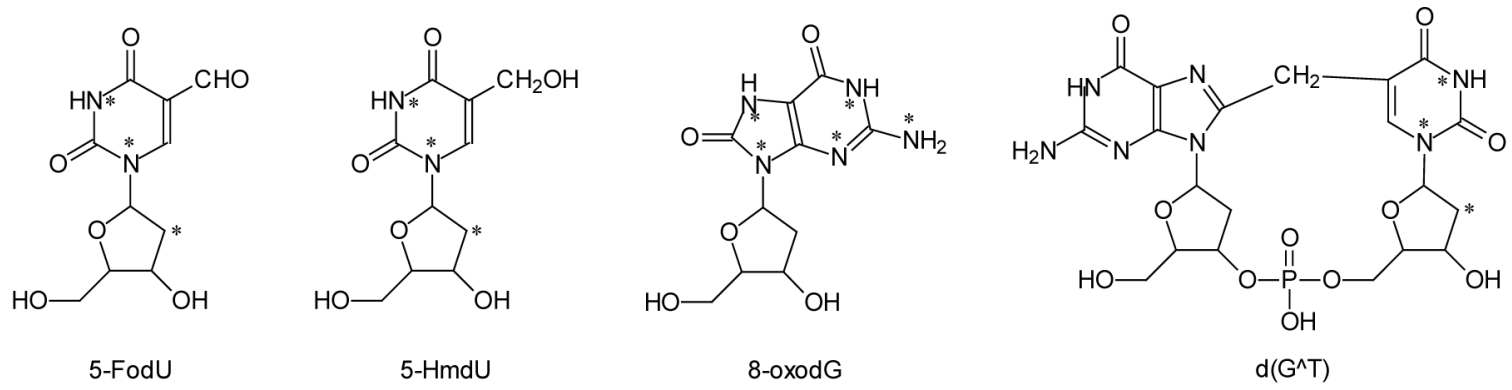

Scheme 1. 


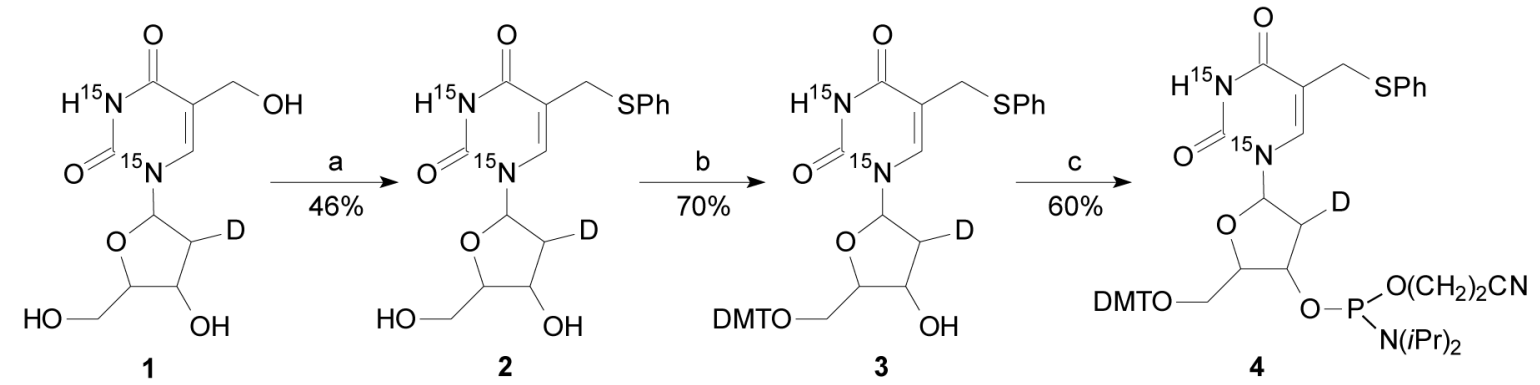

Reagents: a) (i)( $\left(\mathrm{CH}_{3} \mathrm{CO}\right)_{2} \mathrm{O} /$ Pyridine (ii) $\mathrm{PhSH} / \mathrm{TEA} / \mathrm{DMF} / 70^{\circ} \mathrm{C}$ (iii) $\mathrm{NH}_{3} / \mathrm{MeOH}$; b) DMTCl/DMAP/TEA/Pyridine; c) Phosphoramidite $\mathrm{NC}\left(\mathrm{CH}_{2}\right)_{2} \mathrm{OP}(\mathrm{Cl}) \mathrm{N}(\mathrm{Pr})_{2} / \mathrm{DIEA} / \mathrm{CH}_{2} \mathrm{Cl}_{2}$.

Scheme 2. 


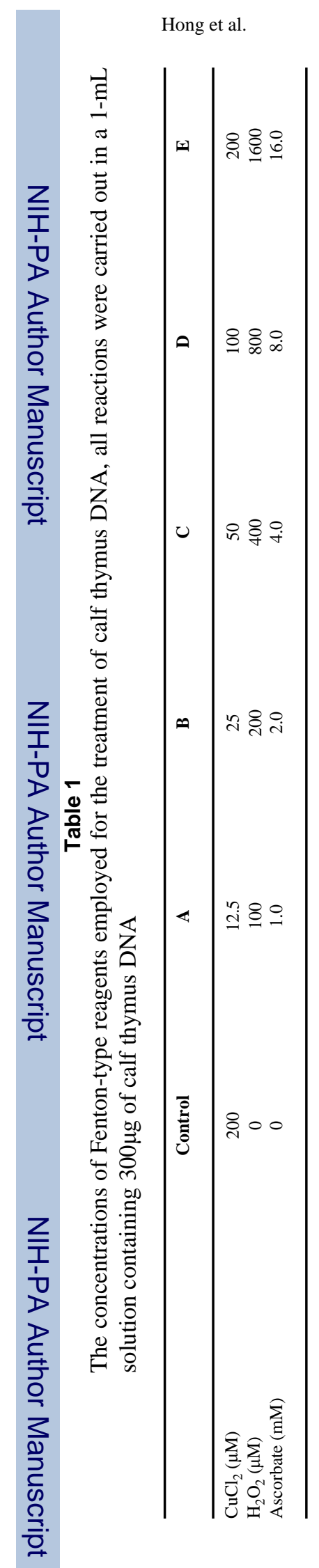

Page 20 